\title{
Impact of Vitamin D on the Cardiovascular System in Advanced Chronic Kidney Disease (CKD) and Dialysis Patients
}

\author{
Anna Gluba-Brzózka ${ }^{1, *}(\mathbb{D})$, Beata Franczyk ${ }^{2}$, Aleksandra Ciałkowska-Rysz ${ }^{3}$, Robert Olszewski ${ }^{4}$ \\ and Jacek Rysz ${ }^{2}$ \\ 1 Department of Nephrology, Hypertension and Family Medicine, WAM Teaching Hospital, 90-549 Lodz, \\ Poland; aniagluba@yahoo.pl \\ 2 Department of Nephrology, Hypertension and Family Medicine, Medical University of Lodz, 90-549 Lodz, \\ Poland; bfranczyk-skora@wp.pl (B.F.); jacek.rysz@umed.lodz.pl (J.R.) \\ 3 Palliative Care Ward, Department of Oncology, Medical University of Lodz, 90-549 Lodz, Poland; \\ olarysz@rmed.pl \\ 4 Department of Ultrasound, Institute of Fundamental Technological Research, \\ Polish Academy of Sciences (IPPT PAN), 02-106 Warsaw, Poland; robert.olszewski@me.com \\ * Correspondence: aniagluba@yahoo.pl
}

Received: 2 May 2018; Accepted: 29 May 2018; Published: 1 June 2018

\begin{abstract}
In patients suffering from chronic kidney disease (CKD), the prevalence of cardiovascular disease is much more common than in the general population. The role of vitamin D deficiency had been underestimated until a significant association was found between vitamin D therapy and survival benefit in haemodialysis patients. Vitamin D deficiency is present even in the early stages of chronic kidney disease. The results of experimental studies have revealed the relationship between vitamin D deficiency and impairment of cardiac contractile function, higher cardiac mass and increased myocardial collagen content. Experimental models propose that intermediate end points for the relationship between vitamin D deficiency and higher risk of cardiovascular disease comprise diminished left ventricular hypertrophy (LVH), enhanced left ventricular diastolic function, and decreased frequency of heart failure. Multiple observational studies have demonstrated an association between the use of active vitamin D therapy in patients on dialysis and with CKD and improved survival. However, there are also many studies indicating important adverse effects of such treatment. Therefore, large randomized trials are required to analyze whether supplementation of vitamin D may affect outcomes and whether it is safe to be used in CKD patients.
\end{abstract}

Keywords: vitamin D; chronic kidney disease; cardiovascular disease; mortality; vitamin D analogues; treatment

\section{Introduction}

In patients suffering from chronic kidney disease (CKD), the prevalence of cardiovascular disease is much more common than in the general population [1]. Their high morbidity and mortality cannot be explained by traditional cardiovascular risk factors, such as advanced age, the presence of diabetes, hypertension, hypertriglyceridemia and low levels of high-density lipoprotein (HDL) cholesterol [2]. According to studies, also abnormalities of calcium, phosphorus, vitamin D, and parathyroid hormone (PTH) are associated with the occurrence of cardiovascular disease [3-5]. Some of them also indicate a relationship between vitamin D deficiency and hypertension, insulin resistance, diabetes, and dyslipidaemia [6-9]. Vitamin D deficiency is present even in the early stages of chronic kidney disease. Numerous observational studies have confirmed low levels of both total 
25-hydroxyvitamin $\mathrm{D} 25(\mathrm{OH}) \mathrm{D}$ which enables the assessment of the adequacy of vitamin $\mathrm{D}$ stores) and 1,25-dihydroxyvitamin $\mathrm{D}(1,25(\mathrm{OH}) 2 \mathrm{D}$-biologically active form of vitamin $\mathrm{D})$, in patients with CKD and end-stage renal disease (ESRD) [10,11].

The role of vitamin D deficiency had been underestimated until a significant association was found between vitamin $\mathrm{D}$ therapy and survival benefit in haemodialysis patients.

Cascade of changes in mineral metabolism occur in the course of chronic kidney disease resulting in the increase in the level of circulating parathyroid hormone and in abnormalities associated with secondary hyperparathyroidism (SHPT). In consequence, higher morbidity and mortality have been observed in patients with CKD stages 3-5D [5,12]. Management of elevated PTH levels in CKD has posed a challenge for several decades.

Patients with chronic kidney disease are frequently suffering from the deficiency of 1,25-dihydroxyvitamin D3 (calcitriol) due to the lack of its precursor-25-hydroxyvitamin D3, and also due to the decreased activity of kidney enzyme $1 \alpha$-hydroxylase, which converts this precursor into active hormone $[13,14]$.

The recommended dietary levels (the requirement of over $97.5 \%$ of the population) for vitamin $\mathrm{D}$ are $600 \mathrm{IU} / \mathrm{d}$ for individuals aged 1-70 years and $800 \mathrm{IU} / \mathrm{d}$ for those older than 70 years [15]. In the opinion of Institute of Medicine Committee, evidences that vitamin D prevented cardiovascular disease, diabetes, or other cardiometabolic outcomes are inconsistent and inconclusive [16]. Moreover, they do not meet criteria for establishing a cause-effect relationship.

Low levels of $25(\mathrm{OH}) \mathrm{D}$ in patients with kidney disease may be due to the loss of vitamin $\mathrm{D}$ binding protein in the urine [17], defective photoproduction in the skin following the exposure to ultraviolet B radiation [18], and likely reduced nutritional intake and sun exposure [19].

\section{Vitamin D and Its Deficiency}

Vitamin D plays an important role in calcium-phosphorus homeostasis, regulation of PTH, and formation and maintenance of bones [3]. Two distinct forms of vitamin D exist-vitamin D2 (ergosterol-derived molecule) and vitamin D3 (cholesterol-derived molecule) [20]. 7-Dehydrocholesterol (pro-vitamin D3) and cholecalciferol (pre-vitamin D3) are precursors of vitamin D3, while ergocalciferol (pre-vitamin D2) is the precursor of vitamin D2. Both vitamin D2 and D3, irrespective of vitamin D source (ultraviolet B-induced synthesis in the skin or nutritional intake), are hydroxylated to 25-hydroxyvitamin $\mathrm{D}[25(\mathrm{OH}) \mathrm{D}]$ (calcidiol) in the liver and then to biologically active form 1,25-dihydroxyvitamin $\mathrm{D}(1,25[\mathrm{OH}] 2 \mathrm{D}$; calcitriol) [21]. The concentration of circulating $25(\mathrm{OH}) \mathrm{D}$ is 1000 -fold higher than that of most potent vitamin D metabolite 1,25-dihydroxyvitamin D $(1,25(\mathrm{OH}) 2 \mathrm{D}$; calcitriol) [22-24]. Renal production of 1,25(OH)2D is strictly controlled by homoeostatic mechanisms, however, it becomes considerably dependent on substrate availability when the level of circulating $25(\mathrm{OH}) \mathrm{D}$ is low $[22,23]$. According to studies, also myocardium and vasculature express $1 \alpha$-hydroxylase and therefore, they can also be the source of $1,25(\mathrm{OH}) 2 \mathrm{D}[22,24]$.

It is estimated that in nearly $1 / 3-1 / 2$ of healthy middle-aged to elderly adults, levels of 25-hydroxy vitamin $\mathrm{D}[25(\mathrm{OH}) \mathrm{D}]$ which is the principal circulating storage form of vitamin $\mathrm{D}$, are low $[4,25]$. Vitamin D insufficiency is usually diagnosed in adults and children when its level drop below $75 \mathrm{nmol} / \mathrm{L}(30 \mathrm{ng} / \mathrm{L})$, while deficiency is identified in case of vitamin D level below $50 \mathrm{nmol} / \mathrm{L}$ (20 ng/L) [4,22,26]. In the course of CKD, renal calcitriol synthesis is diminished as a result of counter-regulatory effects of increasing fibroblast growth factor 23 (FGF23) levels as well as of loss of renal parenchyma $[5,27]$. Both reduced calcitriol levels and hypocalcaemia stimulate the synthesis PTH. The severity of secondary hyperparathyroidism aggravates with worsening renal function leading to parathyroid cell proliferation and hyperplasia as well as the occurrence of abnormalities in bone mineralisation and turnover. Calcitriol or vitamin D receptor activator (VDRA) treatment including paricalcitol, doxercalciferol and alfacalcidol is associated with the suppression of PTH levels, but, at the same time it can lead to the rise in serum calcium, phosphate and FGF23 levels [5]. This inhibition is the result of calcitriol/VDRA action through the vitamin D receptor (VDR) [5]. 
Most effects associated with vitamin D deficiency relate to musculoskeletal system, however, numerous studies point that it adversely affects also cardiovascular system [28]. Vitamin D was suggested to protect against cardiovascular disease, however, the observed effects of vitamin D on CKD patients' outcomes are controversial.

Cardiac cells contractile properties are controlled by direct interaction between calcium, contractile proteins, actin and myosin, and the intracellular handling of calcium [4]. Due to the fact that vitamin D level influences extracellular calcium homeostasis, it alters intracellular calcium thus indirectly affecting cardiac cell contractility [29]. Moreover, active form of vitamin D (1,25-dihydroxyvitamin D) exerts impact also on endothelial cells, and vascular smooth muscle cells through the cytosolic vitamin D receptor (VDR). It affects morphology, proliferation and growth of cardiac cells [4]. According to studies, the therapy with calcitriol enhances the expression and nuclear localization of VDR receptors, boosts cardiac muscle protein expression and diminishes the expression of atrial natriuretic peptides (ANPs) [4,30]. Vitamin D has been shown to modulate the expression of tissue matrix metalloproteinases (MMPs) secreted by activated macrophages during inflammatory responses, thus protecting against the development of atherosclerosis [31]. According to studies, calcitriol is of key importance not only for calcium homeostasis, but also for the homeostasis of electrolytes, volume, and blood pressure [4].

Vast majority of haemodialysis patients suffer from vitamin D deficiency [23,32]. According to studies, either relative or absolute vitamin D deficiency of $25(\mathrm{OH}) \mathrm{D}$ in patients with CKD and ESRD as well as in general population have been associated with all-cause mortality, cardiovascular events, peripheral vascular disease, congestive heart failure, hypertension and the later need for renal replacement therapy $[19,23,33-36]$. The results of experimental studies have revealed the relationship between vitamin D deficiency and impairment of cardiac contractile function [37], higher cardiac mass [38] and increased myocardial collagen content [39]. Experimental models propose that intermediate end points for the relationship between vitamin $\mathrm{D}$ deficiency and higher risk of cardiovascular disease comprise diminished left ventricular hypertrophy (LVH), enhanced left ventricular diastolic function, and decreased frequency of heart failure [40,41]. Cardiomyocyte-specific deletion of the vitamin D receptor gene resulted in cardiac hypertrophy and increased left ventricle (LV) weight [42]. In turn, activated vitamin D therapy was associated with decreased myocardial hypertrophy in experimental models of cardiac hypertrophy [43] and prevented the development of heart failure [44]. Moreover, it has been suggested that vitamin D supplementation may protect cardiovascular health through modulation of the renin-angiotensin system [3]. Li et al. [45,46] suggested that vitamin D was a negative endocrine regulator of renin biosynthesis in vivo, since renin mRNA and protein levels in the kidney of both vitamin D receptor knockout mice and 25-hydroxyvitamin D1 $\alpha$-hydroxylase knockout mice were found to be significantly increased. Moreover, it has been observed that vitamin D receptor knockout mice developed hypertension and cardiac hypertrophy as a result of renin-angiotensin system dysregulation [45,47]. The results of numerous studies confirmed that 1,25-dihydroxyvitamin D3 directly suppressed renin gene expression, and this effect was independent of vitamin D influence on calcium metabolism.

The fact that low vitamin D concentrations relate with altered myocardial calcium flux and increased risk of sudden cardiac death (SCD) may suggest its link to cardiac arrhythmias $[48,49]$. The finding that calcitriol therapy reduced prolonged QT interval (the time between the start of $Q$ wave and the end of $\mathrm{T}$ wave) (risk factor for SCD) in haemodialysis patients is in agreement with the previous suggestion $[50,51]$.

Studies on animal models indicated a relationship between vitamin D3 deficiency and considerable hypocalcaemia, rise in plasma parathyroid hormone level and accumulation of collagen fibres leading to interstitial fibrosis in rats [37]. It seems that the relationship between vitamin D deficiency and cardiovascular disease involve not only atherosclerosis but also vascular calcification. Some studies suggest that excess vitamin D contributes to risk of hypercalcemia and vascular calcification leading to increased survival and morbidity $[52,53]$. In patients with end-stage renal 
disease, in whom renal calcitriol synthesis is diminished, secondary hyperparathyroidism is highly prevalent [54] and it is the primary cause of cardiovascular disease.

Figure 1 summarizes the mechanism contributing to progressive decrease in $1,25(\mathrm{OH}) 2 \mathrm{D}$ in patients with CKD.

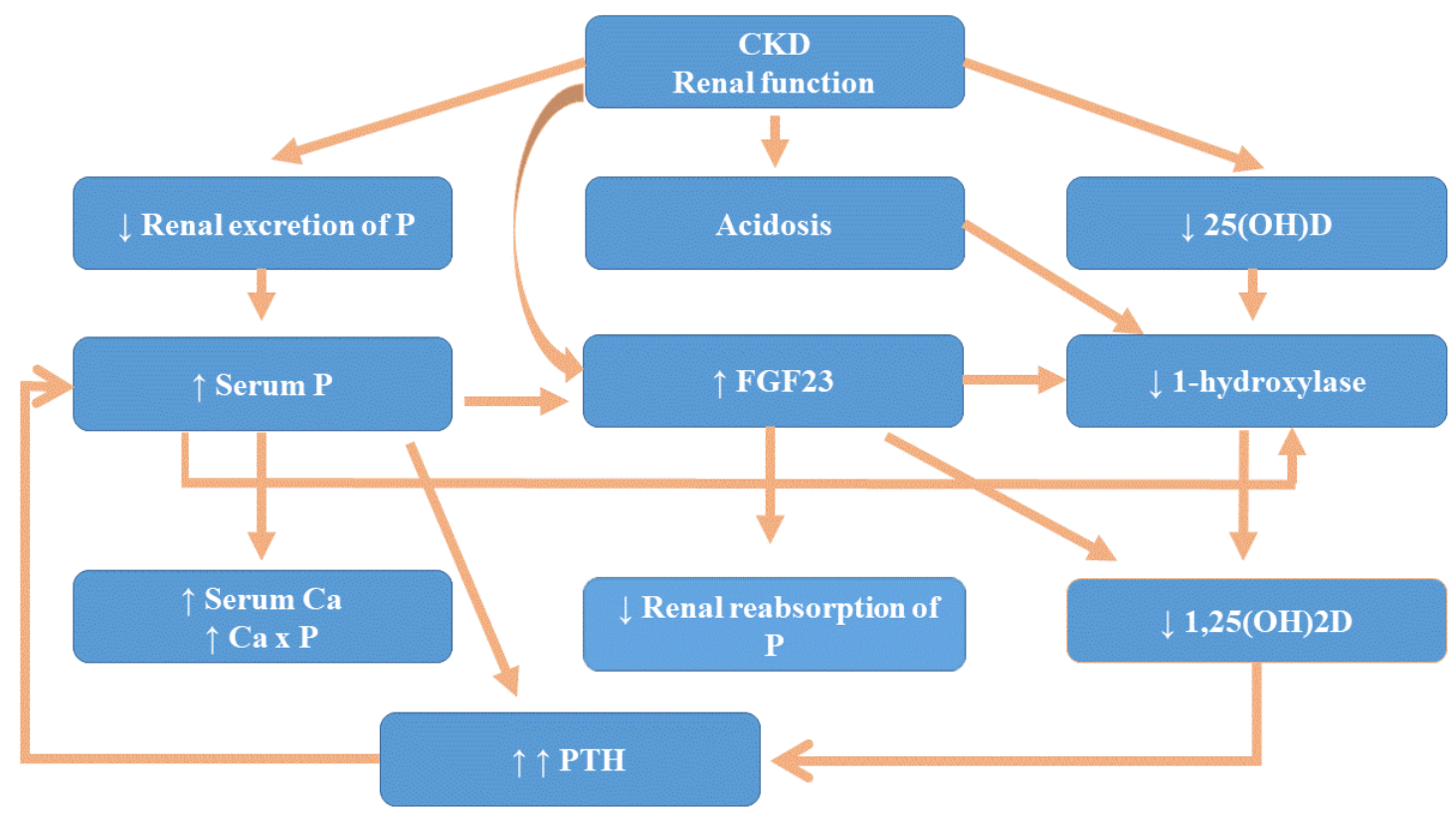

Figure 1. Mechanism contributing to progressive decrease in $1,25(\mathrm{OH}) 2_{2} \mathrm{D}$ in patients with Chronic Kidney Disease (CKD). FGF23: fibroblast growth factor 23; PTH: parathyroid hormone.

\section{Vitamin D Deficiency Treatment}

In patients with CKD, several analogues of vitamin $\mathrm{D}$ have been studied. Paricalcitol and doxercalciferol are D2, while calcitriol is a D3 compound [6]. Doxercalciferol is an inactive pro-hormone which requires the conversion by the liver to its active form (1,25-dihydroxyvitamin D2).

Animal studies, demonstrated that calcitriol and related analogues including paricalcitol enhanced diastolic relaxation and decreased end-diastolic pressures, lowered cardiac mRNA expression and blood levels of natriuretic peptides, and diminished the frequency of congestive heart failure episodes [38,41,48]. Moreover, supplementation of active vitamin D as well as synthetic vitamin $\mathrm{D}$ analogues has been demonstrated to lower the risk of mortality of cardiovascular causes [55] and it inversely correlated with the extent of vascular calcification, independently from other risk factors for ischemic heart disease [56]. Numerous studies have demonstrated decreased mortality in populations of dialysis patients treated with 'active' vitamin $\mathrm{D}$, either calcitriol or vitamin $\mathrm{D}$ receptor activators $[57,58]$.

A prospective, randomized, placebo-controlled trial [39] examining the hypothesis that treatment with oral activated vitamin D (paricalcitol), decreases LV mass in stages 3-5 CKD patients with LV hypertrophy and that it improves systolic and diastolic dysfunction in CKD, demonstrated that 52 weeks of treatment with paricalcitol (at a dose that is sufficient to suppress secondary hyperparathyroidism), failed to reduce LV mass and volume in CKD stages 3-5 patients with LV hypertrophy and it did not modify LV systolic function nor diastolic function. Also, in this study paricalcitol treatment was associated with hypercalcaemia, which occurred in $43.3 \%$ of participants. A meta-analysis performed by Li et al. [59] analysing effects of active vitamin D on cardiovascular outcomes in predialysis patients with CKD demonstrated that calcitriol/VDRA therapy was associated with a reduced incidence of cardiovascular events (relative ratio (RR) 0.27 (95\% confidence interval (CI) 0.13-0.59)) and reduced proteinuria (RR 1.9 (95\% CI 1.34-2.71) in comparison to placebo or no 
treatment. In this study, paricalcitrol administration, but not calcitriol therapy, increased probability of hypercalcaemia with RR 7.85 (95\% CI 2.92-21.10). The hypercalcaemic risk with calcitriol/VDRA is one of the principal concerns with this therapy in CKD, which raises safety concerns. The treatment of severe and progressive SHPT should begin with low doses of calcitriol/VDRA, independent of the initial PTH concentration, and it should be further titrated on the basis of PTH response, to avoid hypercalcaemia.

The meta-analysis of 20 observational studies (11 prospective cohorts, 6 historical cohorts and 3 retrospective cohorts) [7] demonstrated that the therapy with various analogues of active vitamin $\mathrm{D}$ (paricalcitol, calcitriol) was associated with differences in patients' survival. It turned out that treatment with paricalcitol lowered mortality to a slightly greater extent than calcitriol therapy, which could be explained by their differential effects on vascular calcification. The administration of vitamin D was associated with lower mortality compared to those with no treatment (adjusted case mixed baseline model: hazard ratio (HR), 0.74; 95\% confidence interval (95\% CI), 0.67-0.82; $p<0.001$; time-dependent Cox model: HR, 0.71; 95\% CI, 0.57-0.89; $p<0.001)$. Analysis of calcitriol and paricalcitrol separately also provided significant decrease in CAD mortality (HR, 0.63; 95\% CI, 0.50-0.79; $p<0.001)$ and (HR, 0.43 95\% CI, 0.29-0.63; $p<0.001)$, respectively. It has been observed that patients receiving paricalcitol had a survival advantage over those who received calcitriol (HR, 0.95; 95\% CI, 0.91-0.99; $p<0.001)$. Alfacalcidol, calcitriol, paricalcitol and not otherwise specified active vitamin $\mathrm{D}$ treated patients had a $46 \%$ (HR, 0.54; 95\% CI, 0.37-0.80), 43\% (HR, 0.57; 95\% CI, 0.46-0.70), $27 \%(\mathrm{HR}, 0.73 ; 95 \% \mathrm{CI}, 0.62-0.87)$ and 36\% (HR, 0.64; 95\% CI, 0.57-0.72) lower overall mortality risk in comparison to untreated patients. Moreover, with calcitriol, paricalcitol and not otherwise specified active vitamin D supplementation resulted in $26 \%$ decrease (HR, 0.74; 95\% CI, 0.55-0.99), $39 \%(\mathrm{HR}, 0.61 ; 95 \% \mathrm{CI}, 0.58-0.64)$ and 30\% (HR, 70; 95\% CI, 0.63-0.79) in all-cause mortality risk compared to persons without active vitamin $\mathrm{D}$ treatment. The survival advantage was similar in groups of ESRD on dialysis patients and CKD patients not on dialysis. According to other studies, vitamin D (or its analogues - paricalcitol, calcitriol) administration to haemodialysis patients is associated with significant reduction in the risk of all-cause death and of cardiovascular death. The difference in survival of patients receiving paricalcitol was significant at 12 months and increased with time $(p<0.001)$ [60]. The effect of vitamin D analogues therapy may also depend on mean daily or weekly doses. In haemodialysis patients, weekly doses of paricalcitol above $15.0 \mu \mathrm{g}$ were shown to result in an $18 \%$ reduction of mortality risk [61]. Too low doses of vitamin D exerts weak anti-vascular calcification effects in CKD patients, however, its high doses of could be associated with the occurrence of adverse effects, including hypercalcemia, which would overwhelm protective effects.

Shoji et al. [55] study demonstrated that the risk of death was lower in haemodialysis patients treated with alfacalcidol (vitamin D analogue) in comparison to persons not treated with this vitamin. In the study of Drechsler et al. [23] vitamin D status was found to be strongly associated with the risk of SCD. The unadjusted hazard to experience SCD was in haemodialysis patients with severe vitamin $\mathrm{D}$ deficiency 3-fold higher in comparison to those with sufficient 25(OH)D levels (HR: 2.99, 95\% CI: 1.39-6.40). The adjustment for potential confounders and seasonal variation of $25(\mathrm{OH}) \mathrm{D}$ as well as markers of mineral metabolism including PTH, calcium, and phosphate did not influence the association (HR: 2.95, 95\% CI: 1.35-6.46) and (HR: 3.00, 95\% CI: 1.36-6.60), respectively. The analysis, in which $25(\mathrm{OH}) \mathrm{D}$ was treated as a continuous variable demonstrated even higher hazard to die suddenly (59\% per unit decrease in $25(\mathrm{OH}) \mathrm{D}$ levels) [23]. In this study, the risk of stroke was higher in HD patients with lower $25(\mathrm{OH}) \mathrm{D}$ levels. This risk increased by $30 \%$ per unit decrease in $25(\mathrm{OH}) \mathrm{D}$. However, the study of Drechsler et al. [23] failed to demonstrate any association between vitamin D status with MI.

Moreover, some studies indicate that activated vitamin D suppresses renin expression [45] and triggers apoptosis [62]. Administration of injectable vitamin D was shown to increase 2-year survival in comparison to patients who never received it $(75.6 \%$ vs. $58.7 \%, p<0.001)$ and to reduce mortality by $20 \%$ (HR, $0.80 ; 95 \%$ [CI], 0.76 to 0.83 ) [57]. In patients with serum level of PTH $>300 \mathrm{pg} / \mathrm{mL}$ 
( $>33.0 \mathrm{pmol} / \mathrm{L}$ ), the survival advantage for the injectable vitamin D group was $18 \%$ (HR, 0.82; $95 \%$ CI, 0.77 to 0.86) [57]. Multinational, double-blind, randomized placebo-controlled trial PRIOMO (Paricalcitol Capsule Benefits in Renal Failure-Induced Cardiac Morbidity) conducted in 11 countries and involving 227 patients with chronic kidney disease, mild to moderate left ventricular hypertrophy, and preserved left ventricular ejection fraction, analysed whether 48-week treatment with paricalcitol (19-nor-1,25-(OH)2 vitamin D2) reduced left ventricular mass, enhanced diastolic function, diminished CVD events, and improved the level of cardiac biomarkers in patients with LVH and CKD [14]. In this study, paricalcitol at dose $2 \mu \mathrm{g} / \mathrm{d}$ did not reduce left ventricle mass index (LVMI) and did not alter certain echocardiographic measures of diastolic function. However, it did reduce CVD hospitalizations and mitigate the increase in blood levels of BNP, especially in those with evident LVH at baseline. Despite being well-tolerated, paricalcitol treatment was in some patients $(20.9 \%)$ associated with hypercalcemia. Moreover, paricalcitol also increased serum creatinine and consequently reduced creatinine-based measures of estimated glomerular filtration rate (eGFR) [14].

However, the effectiveness of calcitriol/VDRA in the CKD stage 3-4 population has been questioned and the use of the aforementioned compounds have been suspected to be associated with adverse effects, including hypercalcaemia and elevation in fibroblast growth factor 23 (FGF23) levels [5]. According to studies, calcitriol and vitamin D analogues decrease PTH ( $-196 \mathrm{pg} / \mathrm{mL}$ [95\% $\mathrm{CI},-298$ to -94$]$ in dialysis patients and $(-49 \mathrm{pg} / \mathrm{mL}$ [95\% CI, -86 to -13$])$ in pre-dialysis patients) but at the same time they increase serum phosphate and calcium levels $[11,19,63]$.

\section{Mechanisms Associated with Vitamin D Status}

Vitamin D therapy decreases CAD risk due to multi-organ protective effects. There are at least several mechanisms involved in the effect of vitamin D on altered mortality [7] (Figure 2). The influence of vitamin D on mortality was suggested to be related with several mechanisms, including the down-regulation of renin-angiotensin system [64,65], protection of proper endothelial cell function [3], hindering vascular smooth-muscle cell proliferation [66], modulation of inflammatory processes [67], including the activation of pro-inflammatory cytokines as interleukin (IL)-8 and tumour necrosis factor (TNF)-alpha [68] and oxidative stress [69], impeding anticoagulant activity [70], inhibition of myocardial cell hypertrophy and proliferation [71] and finally the improvement of insulin secretion and sensitivity [72]. Despite the fact that the exact mechanism of CKD patient mortality has not been resolved, studies indicate that it can be associated with over vascular calcifications, left ventricle hypertrophy and in consequence left ventricle dysfunction [7]. Increased mortality risk in patients with low 25(OH)D levels may be the consequence of the relationship between vitamin D deficiency with cardiovascular risk factors, such as: type 2 diabetes mellitus [73], arterial hypertension [74], malnutrition, and inflammation [23]. In a double-blind, randomized, placebo-controlled trial, vitamin $\mathrm{D}$ supressed pro-inflammatory state via the down-regulation of nuclear factor- $\mathrm{k} B$ activity, hampering of the production of IL-6, IL-12, interferon-, and TNF while increasing that of anti-inflammatory cytokines [75]. Timms et al. [31] suggested that vitamin D administration in case of its deficiency may inhibit several aspects of the inflammatory response to cardiovascular injury as well as slow down atherosclerotic plaque progression and limit plaque rupture. Moreover, inverse correlation has been observed between serum vitamin D levels and coronary calcification [56]. Vitamin D may indirectly prevent inflammation and the stimulation of endothelial progenitor cells (EPCs) and in this way it protects against the development of congestive heart failure [76]. Experiments on animal models (rats) indicated that vitamin D deficiency promoted myocardial hypertrophy, greater heart weight/body weight ratio and extracellular matrix production in myocardial tissue in rats, while administration of 1,25-dihydroxyvitamin D3 inhibited cell proliferation of primary ventricular myocytes $[37,77]$. These observations were confirmed in haemodialysis patients, in whom vitamin D therapy (calcitriol) was associated with the reduction of left ventricle hypertrophy (LVH) accompanied by a considerable decrease in plasma renin activity and plasma angiotensin II levels [78]. The finding that 1,25-dihydroxyvitamin D3 hampered the expression of a skeletal actin and ANP 
gene (both associated with myocardial hypertrophy and heart failure) suggest its role in cardiac homeostasis [79]. The results of Multi-Ethnic Study of Atherosclerosis [80] suggest that vitamin D deficiency is prospectively associated with elevated risk of coronary artery calcification (a measure of coronary atherosclerosis). The association of 25-hydroxyvitamin D with incident CAC was observed to be stronger among participants with lower estimated GFR. Overt association of vitamin D deficiency with SCD but not with MI may suggest that atherosclerosis related to vitamin D deficiency might not be the main pathophysiological mechanism. The results of animal studies demonstrated myocardial hypertrophy and dysfunction with a hypercontractile state in both conditions of vitamin D deficiency as well as in VDR knockout models [23,30,81].

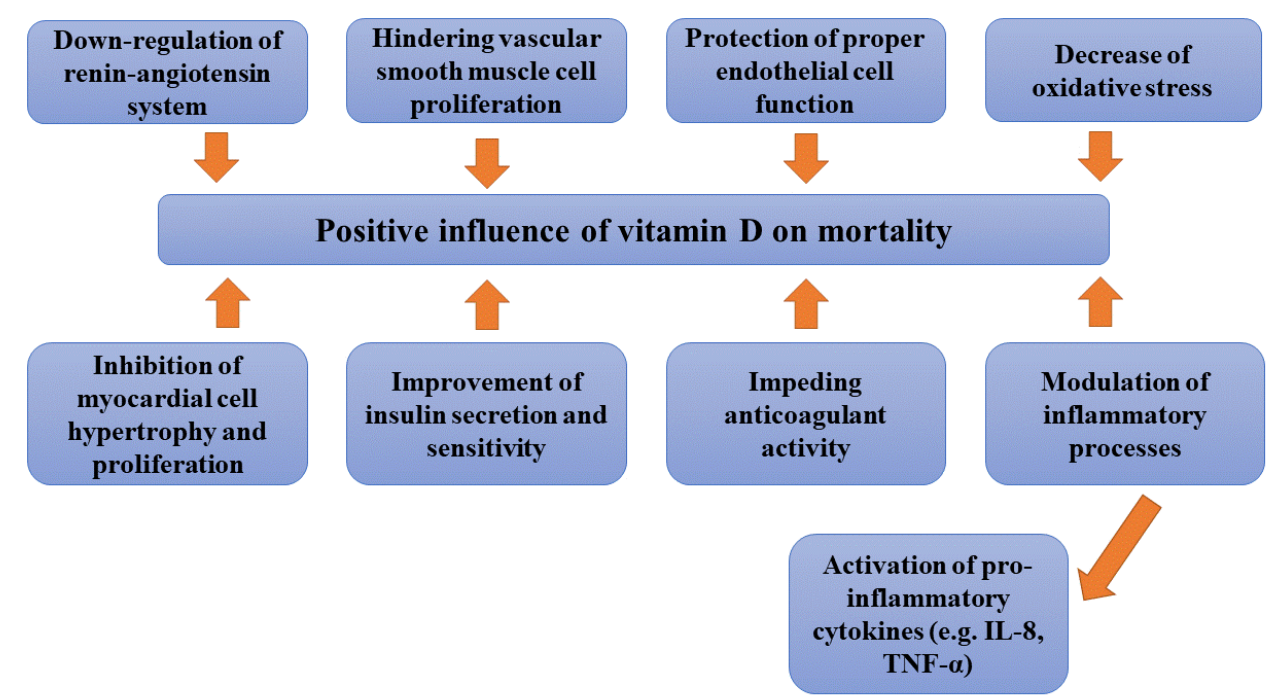

Figure 2. Mechanisms involved in the effect of vitamin D on altered mortality.

\section{Guidelines}

The Kidney Disease Improving Global Outcomes (KDIGO) CKD-MBD guidelines (2017) [82] suggest that in patients with CKD G3a-G5D, 25(OH)D (calcidiol) levels might be measured, and that vitamin $\mathrm{D}$ deficiency and insufficiency should be corrected using treatment strategies recommended for the general population (2C). Moreover, in patients with CKD G3a-G5 not on dialysis and with levels of intact PTH progressively rising or persistently above the upper normal limit for the assay, they recommend that PTH level ought to be evaluated for modifiable factors, including hyperphosphatemia, hypocalcaemia, high phosphate intake, and vitamin D deficiency (2C). According to these guidelines, in adult patients with CKD G3a-G5 not on dialysis, calcitriol and vitamin D analogues should not be routinely used (2C) since it is reasonable to reserve the use of calcitriol and vitamin D analogues for patients with CKD G4-G5 with severe and progressive hyperparathyroidism (Not Graded). However, in children, calcitriol and vitamin D analogues may be considered in order to maintain serum calcium levels in the age-appropriate normal range (Not Graded) [82].

\section{Summary}

Multiple observational studies have demonstrated an association between the use of active vitamin D therapy in patients on dialysis and with CKD and improved survival $[55,57,83,84]$. However, there are also many studies indicating important adverse effects of such treatment. Therefore, large randomized trials are required to analyse whether supplementation of vitamin D may affect outcomes and whether it is safe to be used in CKD patients.

Author Contributions: A.G.-B., B.F. and A.C.-R. prepared initial version of this manuscript, R.O. and J.R. reviewed the manuscript and prepared the final version. 
Conflicts of Interest: Authors declare no conflict of interest.

\section{References}

1. Foley, R.N.; Parfrey, P.S.; Sarnak, M.I. Clinical epidemiology of cardiovascular disease in chronic renal disease. Am. J. Kidney Dis. 1998, 32, S112-S119. [CrossRef] [PubMed]

2. Longenecker, J.C.; Coresh, J.; Powe, N.R.; Levey, A.S.; Fink, N.E.; Martin, A.; Klag, M.J. Traditional cardiovascular disease risk factors in dialysis patients compared with the general population: The CHOICE Study. J. Am. Soc. Nephrol. 2002, 13, 1918-1927. [CrossRef] [PubMed]

3. Levin, A.; Li, Y.C. Vitamin D and its analogues: Do they protect against cardiovascular disease in patients with kidney disease? Kidney Int. 2005, 68, 1973-1981. [CrossRef] [PubMed]

4. Fanari, Z.; Hammami, S.; Hammami, M.B.; Hammami, S.; Abdellatif, A. Vitamin D deficiency plays an important role in cardiac disease and affects patient outcome: Still a myth or a fact that needs exploration? J. Saudi Heart Assoc. 2015, 27, 264-271. [CrossRef] [PubMed]

5. Toussaint, N.D.; Damasiewicz, M.J. Do the benefits of using calcitriol and other vitamin D receptor activators in patients with chronic kidney disease outweigh the harms? Nephrology 2017, 22, 51-56. [CrossRef] [PubMed]

6. Sprague, S.M. Mortality risk among hemodialysis patients receiving different vitamin D analogs. Kidney Int. 2007, 72, 895. [CrossRef] [PubMed]

7. Zheng, Z.; Shi, H.; Jia, J.; Li, D.; Lin, S. Vitamin D supplementation and mortality risk in chronic kidney disease: A meta-analysis of 20 observational studies. BMC Nephrol. 2013, 14, 199. [CrossRef] [PubMed]

8. Forman, J.P.; Giovannucci, E.; Holmes, M.D.; Bischoff-Ferrari, H.A.; Tworoger, S.S.; Willett, W.C.; Curhan, G.C. Plasma 25-hydroxyvitamin D levels and risk of incident hypertension. Hypertension 2007, 49, 1063-1069. [CrossRef] [PubMed]

9. Pittas, A.G.; Dawson-Hughes, B.; Li, T.; Van Dam, R.M.; Willett, W.C.; Manson, J.E.; Hu, F.B. Vitamin D and calcium intake in relation to type 2 diabetes in women. Diabetes Care 2006, 29, 650-656. [CrossRef] [PubMed]

10. Wolf, M.; Shah, A.; Gutierrez, O.; Ankers, E.; Monroy, M.; Tamez, H.; Steele, D.; Chang, Y.; Camargo, C.A., Jr.; Tonelli, M.; et al. Vitamin D levels and early mortality among incident hemodialysis patients. Kidney Int. 2007, 72, 1004-1013. [CrossRef] [PubMed]

11. Palmer, S.C.; McGregor, D.O.; Craig, J.C.; Elder, G.; Macaskill, P.; Strippoli, G.F. Vitamin D compounds for people with chronic kidney disease not requiring dialysis. Cochrane Database Syst. Rev. 2009, 4, CD008175. [CrossRef]

12. Block, G.A.; Klassen, P.S.; Lazarus, J.M.; Ofsthun, N.; Lowrie, E.G.; Chertow, G.M. Mineral metabolism, mortality, and morbidity in maintenance hemodialysis. J. Am. Soc. Nephrol. 2004, 15, 2208-2218. [CrossRef] [PubMed]

13. Quarles, L.D. Endocrine functions of bone in mineral metabolism regulation. J. Clin. Investig. 2008, 118, 3820-3828. [CrossRef] [PubMed]

14. Thadhani, R.; Appelbaum, E.; Pritchett, Y.; Chang, Y.; Wenger, J.; Tamez, H.; Bhan, I.; Agarwal, R.; Zoccali, C.; Wanner, C.; et al. Vitamin D therapy and cardiac structure and function in patients with chronic kidney disease: The PRIMO randomized controlled trial. JAMA 2012, 307, 674-684. [CrossRef] [PubMed]

15. Shapses, S.A.; Manson, J.E. Vitamin D and prevention of cardiovascular disease and diabetes: Why the evidence falls short. JAMA 2011, 305, 2565-2566. [CrossRef] [PubMed]

16. Institute of Medicine. Dietary Reference Intakes for Calcium and Vitamin D. Available online: http://books. nap.edu/openbook.php?record_id=13050 (accessed on 20 April 2018).

17. Koenig, K.G.; Lindberg, J.S.; Zerwekh, J.E.; Padalino, P.K.; Cushner, H.M.; Copley, J.B. Free and total 1,25-dihydroxyvitamin D levels in subjects with renal disease. Kidney Int. 1992, 41, 161-165. [CrossRef] [PubMed]

18. Jacob, A.I.; Sallman, A.; Santiz, Z.; Hollis, B.W. Defective photoproduction of cholecalciferol in normal and uremic humans. J. Nutr. 1984, 114, 1313-1319. [CrossRef] [PubMed]

19. Melamed, M.L.; Thadhani, R.I. Vitamin D Therapy in Chronic Kidney Disease and End Stage Renal Disease. Clin. J. Am. Soc. Nephrol. 2012, 7, 358-365. [CrossRef] [PubMed]

20. Ahmed, M.S.; Shoker, A. Vitamin D metabolites; protective versus toxic properties: Molecular and cellular perspectives. Nephrol. Rev. 2010, 2, 19-26. 
21. Alshahrani, F.; Aljohani, N. Vitamin D: Deficiency, Sufficiency and Toxicity. Nutrients 2013, 5, 3605-3616. [CrossRef] [PubMed]

22. Holick, M.F. Vitamin D deficiency. N. Engl. J. Med. 2007, 357, 266-281. [CrossRef] [PubMed]

23. Drechsler, C.; Pilz, S.; Obermayer-Pietsch, B.; Verduijn, M.; Tomaschitz, A.; Krane, V.; Espe, K.; Dekker, F.; Brandenburg, V.; März, W.; et al. Vitamin D deficiency is associated with sudden cardiac death, combined cardiovascular events, and mortality in haemodialysis patients. Eur. Heart J. 2010, 31, 2253-2261. [CrossRef] [PubMed]

24. Peterlik, M.; Cross, H.S. Vitamin D and calcium deficits predispose for multiple chronic diseases. Eur. J. Clin. Investig. 2005, 35, 290-304. [CrossRef] [PubMed]

25. Samelson, E.J.; Kiel, D.P.; Broe, K.E.; Zhang, Y.; Cupples, L.A.; Hannan, M.T.; Wilson, P.W.; Levy, D.; Williams, S.A.; Vaccarino, V. Metacarpal cortical area and risk of coronary heart disease: The Framingham Study. Am. J. Epidemiol. 2004, 159, 589-595. [CrossRef] [PubMed]

26. Contreras, J.J.; Hiestand, B.; O'Neill, J.C.; Schwartz, R.; Nadkarni, M. Vitamin D deficiency in children with fractures. Pediatr. Emerg. Care 2014, 30, 777-781. [CrossRef] [PubMed]

27. Gutierrez, O. Fibroblast growth factor-23 mitigates hyperphosphatemia but accentuates calcitriol deficiency in chronic kidney disease. J. Am. Soc. Nephrol. 2005, 16, 2205-2215. [CrossRef] [PubMed]

28. Rajasree, S.; Rajpal, K.; Kartha, C.C.; Sarma, P.S.; Kutty, V.R.; Iyer, C.S.P.; Girija, G. Serum 25-hydroxyvitamin D3 levels are elevated in South Indian patients with ischemic heart disease. Eur. J. Epidemiol. 2001, 17, 567-571. [CrossRef] [PubMed]

29. Weber, K.T.; Simpson, R.U.; Carbone, L.D. Vitamin D and calcium dyshomeostasis-associated heart failure. Heart 2008, 94, 540-541. [CrossRef] [PubMed]

30. Nibbelink, K.A.; Tishkoff, D.X.; Hershey, S.D.; Rahman, A.; Simpson, R.U. 1,25(OH)2-vitamin D3 actions on cell proliferation, size, gene expression, and receptor localization, in the HL-1 cardiac myocyte. J. Steroid Biochem. Mol. Biol. 2007, 103, 533-537. [CrossRef] [PubMed]

31. Timms, P.M.; Mannan, N.; Hitman, G.A.; Noonan, K.; Mills, P.G.; Syndercombe-court, D.; Aganna, E.; Price, C.P.; Boucher, B.J. Circulating MMP9, vitamin D and variation in the TIMP-1 response with VDR genotype: Mechanisms for inflammatory damage in chronic disorders? QJM 2002, 95, 787-796. [CrossRef] [PubMed]

32. Wang, A.Y.; Lam, C.W.; Sanderson, J.E.; Wang, M.; Chan, I.H.; Lui, S.F.; Sea, M.M.; Woo, J. Serum 25-hydroxyvitamin D status and cardiovascular outcomes in chronic peritoneal dialysis patients: A 3-y prospective cohort study. Am. J. Clin. Nutr. 2008, 87, 1631-1638. [CrossRef] [PubMed]

33. Zittermann, A.; Schleithoff, S.S.; Frisch, S.; Götting, C.; Kuhn, J.; Koertke, H.; Kleesiek, K.; Tenderich, G.; Koerfer, R. Circulating calcitriol concentrations and total mortality. Clin. Chem. 2009, 55, 1163-1170. [CrossRef] [PubMed]

34. Melamed, M.L.; Michos, E.D.; Post, W.; Astor, B. 25-hydroxyvitamin D levels and the risk of mortality in the general population. Arch. Intern. Med. 2008, 168, 1629-1637. [CrossRef] [PubMed]

35. Melamed, M.L.; Muntner, P.; Michos, E.D.; Uribarri, J.; Weber, C.; Sharma, J.; Raggi, P. Serum 25-hydroxyvitamin D levels and the prevalence of peripheral arterial disease: Results from NHANES 2001 to 2004. Arterioscler. Thromb. Vasc. Biol. 2008, 28, 1179-1185. [CrossRef] [PubMed]

36. Wang, T.J.; Pencina, M.J.; Booth, S.L.; Jacques, P.F.; Ingelsson, E.; Lanier, K.; Benjamin, E.J.; D’Agostino, R.B.; Wolf, M.; Vasan, R.S. Vitamin D deficiency and risk of cardiovascular disease. Circulation 2008, 117, 503-511. [CrossRef] [PubMed]

37. Weishaar, R.E.; Kim, S.N.; Saunders, D.E.; Simpson, R.U. Involvement of vitamin D3 with cardiovascular function. III. Effects on physical and morphological properties. Am. J. Physiol. 1990, 258, E134-E142. [CrossRef] [PubMed]

38. Weishaar, R.E.; Simpson, R.U. Vitamin D3 and cardiovascular function in rats. J. Clin. Investig. 1987, 79, 1706-1712. [CrossRef] [PubMed]

39. Wang, A.Y.M.; Fang, F.; Chan, J.; Wen, Y.Y.; Qing, S.; Chan, I.H.S.; Lo, G.; Lai, K.N.; Lo, W.K.; Lam, C.W.K.; et al. Effect of paricalcitol on left ventricular mass and function in CKD-The OPERA trial. J. Am. Soc. Nephrol. 2014, 25, 175-186. [CrossRef] [PubMed]

40. Bodyak, N.; Ayus, J.C.; Achinger, S.; Shivalingappa, V.; Ke, Q.; Chen, Y.S.; Rigor, D.L.; Stillman, I.; Tamez, H.; Kroeger, P.E.; et al. Activated vitamin D attenuates left ventricular abnormalities induced by dietary sodium in Dahl salt-sensitive animals. Proc. Natl. Acad. Sci. USA 2007, 104, 16810-16815. [CrossRef] [PubMed] 
41. Przybylski, R.; McCune, S.; Hollis, B.; Simpson, R.U. Vitamin D deficiency in the spontaneously hypertensive heart failure (SHHF) prone rat. Nutr. Metab. Cardiovasc. Dis. 2010, 20, 641-646. [CrossRef] [PubMed]

42. Chen, S.; Law, C.S.; Grigsby, C.L.; Olsen, K.; Hong, T.T.; Zhang, Y.; Yeghiazarians, Y.; Gardner, D.G. Cardiomyocyte-specific deletion of the vitamin D receptor gene results in cardiac hypertrophy. Circulation 2011, 124, 1838-1847. [CrossRef] [PubMed]

43. Wu, J.; Garami, M.; Cheng, T.; Gardner, D.G. 1,25(OH)2 vitamin D3, and retinoic acid antagonize endothelin-stimulated hypertrophy of neonatal rat cardiac myocytes. J. Clin. Investig. 1996, 97, 1577-1588. [CrossRef] [PubMed]

44. Bae, S.; Yalamarti, B.; Ke, Q.; Choudhury, S.; Yu, H.; Karumanchi, S.A.; Kroeger, P.; Thadhani, R.; Kang, P.M. Preventing progression of cardiac hypertrophy and development of heart failure by paricalcitol therapy in rats. Cardiovasc. Res. 2011, 91, 632-639. [CrossRef] [PubMed]

45. Li, Y.C.; Kong, J.; Wei, M.; Chen, Z.F.; Liu, S.Q.; Cao, L.P. 1,25-Dihydroxyvitamin D(3) is a negative endocrine regulator of the renin-angiotensin system. J. Clin. Investig. 2002, 110, 229-238. [CrossRef] [PubMed]

46. Li, Y.C. Vitamin D regulation of the renin-angiotensin system. J. Cell Biochem. 2003, 88, 327-331. [CrossRef] [PubMed]

47. Xiang, W.; Kong, J.; Chen, S.; Cao, L.P.; Qiao, G.; Zheng, W.; Liu, W.; Li, X.; Gardner, D.G.; Li, Y.C. Cardiac hypertrophy in vitamin D receptor knockout mice: Role of the systemic and cardiac renin-angiotensin systems. Am. J. Physiol. Endocrinol. Metab. 2005, 288, E125-E132. [CrossRef] [PubMed]

48. Tishkoff, D.X.; Nibbelink, K.A.; Holmberg, K.H.; Dandu, L.; Simpson, R.U. Functional vitamin D receptor (VDR) in the t-tubules of cardiac myocytes: VDR knockout cardiomyocyte contractility. Endocrinology 2008, 149, 558-564. [CrossRef] [PubMed]

49. Pilz, S.; Tomaschitz, A.; Drechsler, C.; Dekker, J.M.; März, W. Vitamin D deficiency and myocardial diseases. Mol. Nutr. Food Res. 2010, 54, 1103-1113. [CrossRef] [PubMed]

50. Kim, H.W.; Park, C.W.; Shin, Y.S.; Kim, Y.S.; Shin, S.J.; Kim, Y.S.; Choi, E.J.; Chang, Y.S.; Bang, B.K. Calcitriol regresses cardiac hypertrophy and QT dispersion in secondary hyperparathyroidism on hemodialysis. Nephron Clin. Pract. 2006, 102, c21-c29. [CrossRef] [PubMed]

51. Yamshchikov, A.V.; Desai, N.S.; Blumberg, H.M.; Ziegler, T.R.; Tangpricha, V. Vitamin D for treatment and prevention of infectious diseases: A systematic review of randomized controlled trials. Endocr. Pract. 2009, 15, 438-449. [CrossRef] [PubMed]

52. Goldsmith, D.J.A.; Covic, A.; Sambrook, P.A.; Ackrill, P. Vascular calcification in long-term haemodialysis patients in a single unit: A retrospective analysis. Nephron 1997, 77, 37-43. [CrossRef] [PubMed]

53. Milliner, D.S.; Zinsmeister, A.R.; Lieberman, E.; Landing, B. Soft tissue calcification in pediatric patients with end-stage renal disease. Kidney Int. 1990, 38, 931-936. [CrossRef] [PubMed]

54. Drüeke, T.B.; McCarron, D.A. Paricalcitol as compared with calcitriol in patients undergoing hemodialysis. N. Engl. J. Med. 2003, 349, 496-499. [CrossRef] [PubMed]

55. Shoji, T.; Shinohara, K.; Kimoto, E.; Emoto, M.; Tahara, H.; Koyama, H.; Inaba, M.; Fukumoto, S.; Ishimura, E.; Miki, T.; et al. Lower risk for cardiovascular mortality in oral 1alpha-hydroxy vitamin D3 users in a haemodialysis population. Nephrol. Dial. Transplant. 2004, 19, 179-184. [CrossRef] [PubMed]

56. Watson, K.E.; Abrolat, M.L.; Malone, L.L.; Hoeg, J.M.; Doherty, T.; Detrano, R.; Demer, L.L. Active serum vitamin D levels are inversely correlated with coronary calcification. Circulation 1997, 96, 1755-1760. [CrossRef] [PubMed]

57. Teng, M.; Wolf, M.; Ofsthun, M.N.; Lazarus, J.M.; Hernán, M.A.; Camargo, C.A.; Thadhani, R. Activated injectable vitamin D and hemodialysis survival: A historical cohort study. J. Am. Soc. Nephrol. 2005, 16, 1115-1125. [CrossRef] [PubMed]

58. Naves-Díaz, M.; Alvarez-Hernández, D.; Passlick-Deetjen, J.; Guinsburg, A.; Marelli, C.; Rodriguez-Puyol, D.; Cannata-Andía, J.B. Oral active vitamin D is associated with improved survival in hemodialysis patients. Kidney Int. 2008, 74, 1070-1078. [CrossRef] [PubMed]

59. Li, X.H.; Feng, L.; Yang, Z.H.; Liao, Y.H. The effect of active vitamin D on cardiovascular outcomes in predialysis chronic kidney diseases: A systematic review and meta-analysis. Nephrology 2015, 20, 706-714. [CrossRef] [PubMed]

60. Teng, M.; Wolf, M.; Lowrie, E.; Ofsthun, N.; Lazarus, J.M.; Thadhani, R. Survival of patients undergoing hemodialysis with paricalcitol or calcitriol therapy. N. Engl. J. Med. 2003, 349, 446-456. [CrossRef] [PubMed] 
61. Kalantar-Zadeh, K.; Kuwae, N.; Regidor, D.L.; Kovesdy, C.P.; Kilpatrick, R.D.; Shinaberger, C.S.; McAllister, C.J.; Budoff, M.J.; Salusky, I.B.; Kopple, J.D. Survival predictability of time-varying indicators of bone disease in maintenance hemodialysis patients. Kidney Int. 2006, 70, 771-780. [CrossRef] [PubMed]

62. Elstner, E.; Linker-Israeli, M.; Said, J.; Umiel, T.; de Vos, S.; Shintaku, I.P.; Heber, D.; Binderup, L.; Uskokovic, M.; Koeffler, H.P. 20-Epi-vitamin D3 analogues: A novel class of potent inhibitors of proliferation and inducers of differentiation of human breast cancer cell lines. Cancer Res. 1995, 55, 2822-2830. [PubMed]

63. Palmer, S.C.; McGregor, D.O.; Craig, J.C.; Elder, G.; Macaskill, P.; Strippoli, G.F. Vitamin D compounds for people with chronic kidney disease requiring dialysis. Cochrane Database Syst. Rev. 2009, 4, CD005633. [CrossRef]

64. Rammos, G.; Tseke, P.; Ziakka, S. Vitamin D, the renin-angiotensin system, and insulin resistance. Int. Urol. Nephrol. 2008, 40, 419-426. [CrossRef] [PubMed]

65. Swedberg, K.; Eneroth, P.; Kjekshus, J.; Wilhelmsen, L. Hormones regulating cardiovascular function in patients with severe congestive heart failure and their relation to mortality. CONSENSUS Trial Study Group. Circulation 1990, 82, 1730-1736. [CrossRef] [PubMed]

66. Carthy, E.P.; Yamashita, W.; Hsu, A.; Ooi, B.S. 1,25-Dihydroxyvitamin D3 and rat vascular smooth muscle cell growth. Hypertension 1989, 13, 954-959. [CrossRef] [PubMed]

67. Gysemans, C.A.; Cardozo, A.K.; Callewaert, H.; Giulietti, A.; Hulshagen, L.; Bouillon, R.; Eizirik, D.L.; Mathieu, C. 1,25-Dihydroxyvitamin D3 modulates expression of chemokines and cytokines in pancreatic islets: Implications for prevention of diabetes in non-obese diabetic mice. Endocrinology 2005, 146, 1956-1964. [CrossRef] [PubMed]

68. Damås, J.K.; Gullestad, L.; Aass, H.; Simonsen, S.; Fjeld, J.G.; Wikeby, L.; Ueland, T.; Eiken, H.G.; Frøland, S.S.; Aukrust, P. Enhanced gene expression of chemokines and their corresponding receptors in mononuclear blood cells in chronic heart failure-Modulatory effect of intravenous immunoglobulin. J. Am. Coll. Cardiol. 2001, 38, 187-193. [CrossRef]

69. Cesselli, D.; Jakoniuk, I.; Barlucchi, L.; Beltrami, A.P.; Hintze, T.H.; Nadal-Ginard, B.; Kajstura, J.; Leri, A.; Anversa, P. Oxidative stress-mediated cardiac cell death is a major determinant of ventricular dysfunction and failure in dog dilated cardiomyopathy. Circ. Res. 2001, 89, 279-286. [CrossRef] [PubMed]

70. Ohsawa, M.; Koyama, T.; Yamamoto, K.; Hirosawa, S.; Kamei, S.; Kamiyama, R. 1,25-dihydroxyvitamin D(3) and its potent synthetic analogs downregulate tissue factor and upregulate thrombomodulin expression in monocytic cells, counteracting the effects of tumor necrosis factor and oxidized LDL. Circulation 2000, 102, 2867-2872. [CrossRef] [PubMed]

71. Simpson, R.U.; Hershey, S.H.; Nibbelink, K.A. Characterization of heart size and blood pressure in the vitamin D receptor knockout mouse. J. Steroid Biochem. Mol. Biol. 2007, 103, 521-524. [CrossRef] [PubMed]

72. Chiu, K.C.; Chu, A.; Go, V.L.; Saad, M.F. Hypovitaminosis D is associated with insulin resistance and beta cell dysfunction. Am. J. Clin. Nutr. 2004, 79, 820-825. [CrossRef] [PubMed]

73. Pittas, A.G.; Lau, J.; Hu, F.B.; Dawson-Hughes, B. The role of vitamin D and calcium in type 2 diabetes. A systematic review and meta-analysis. J. Clin. Endocrinol. Metab. 2007, 92, 2017-2029. [CrossRef] [PubMed]

74. Pilz, S.; Tomaschitz, A.; Ritz, E.; Pieberm, T.R. Vitamin D status and arterial hypertension: A systematic review. Nat. Rev. Cardiol. 2009, 6, 621-630. [CrossRef] [PubMed]

75. Schleithoff, S.S.; Zittermann, A.; Tenderich, G.; Berthold, H.K.; Stehle, P.; Koerfer, R. Vitamin D supplementation improves cytokine profiles in patients with congestive heart failure: A double-blind, randomized, placebo-controlled trial. Am. J. Clin. Nutr. 2006, 83, 754-759. [CrossRef] [PubMed]

76. Zittermann, A.; Schleithoff, S.S.; Tenderich, G.; Berthold, H.K.; Körfer, R.; Stehle, P. Low vitamin D status: A contributing factor in the pathogenesis of congestive heart failure? J. Am. Coll. Cardiol. 2003, 41, 105-112. [CrossRef]

77. Weishaar, R.E.; Simpson, R.U. The involvement of the endocrine system in regulating cardiovascular function: Emphasis on vitamin D3. Endocr. Rev. 1989, 10, 351-365. [CrossRef] [PubMed]

78. Park, C.W.; Oh, Y.S.; Shin, Y.S.; Kim, C.M.; Kim, Y.S.; Kim, S.Y.; Choi, E.J.; Chang, Y.S.; Bang, B.K. Intravenous calcitriol regresses myocardial hypertrophy in hemodialysis patients with secondary hyperparathyroidism. Am. J. Kidney Dis. 1999, 33, 73-81. [CrossRef]

79. O'Connell, T.D.; Berry, J.E.; Jarvis, A.K.; Somerman, M.J.; Simpson, R.U. 1,25-Dihydroxyvitamin D3 regulation of cardiac myocyte proliferation and hypertrophy. Am. J. Physiol. 1997, 272, H1751-H1758. [CrossRef] [PubMed] 
80. De Boer, I.H.; Kestenbaum, B.; Shoben, A.B.; Michos, E.D.; Sarnak, M.J.; Siscovick, D.S. 25-hydroxyvitamin D levels inversely associate with risk for developing coronary artery calcification. J. Am. Soc. Nephrol. 2009, 20, 1805-1812. [CrossRef] [PubMed]

81. Green, J.J.; Robinson, D.A.; Wilson, G.E.; Simpson, R.U.; Westfall, M.V. Calcitriol modulation of cardiac contractile performance via protein kinase C. J. Mol. Cell. Cardiol. 2006, 41, 350-359. [CrossRef] [PubMed]

82. KDIGO 2017 Clinical Practice Guideline Update for the Diagnosis, Evaluation, Prevention, and Treatment of Chronic Kidney Disease-Mineral and Bone Disorder (CKD-MBD). Kidney Int. Suppl. 2017, 7, 1-59.

83. Wolf, M.; Betancourt, J.; Chang, Y.; Shah, A.; Teng, M.; Tamez, H.; Gutierrez, O.; Camargo, C.A., Jr.; Melamed, M.; Norris, K.; et al. Impact of activated vitamin D and race on survival among hemodialysis patients. J. Am. Soc. Nephrol. 2008, 19, 1379-1388. [CrossRef] [PubMed]

84. Kovesdy, C.P.; Ahmadzadeh, S.; Anderson, J.E.; Kalantar-Zadeh, K. Association of activated vitamin D treatment and mortality in chronic kidney disease. Arch. Intern. Med. 2008, 168, 397-403. [CrossRef] [PubMed]

(C) 2018 by the authors. Licensee MDPI, Basel, Switzerland. This article is an open access article distributed under the terms and conditions of the Creative Commons Attribution (CC BY) license (http:/ / creativecommons.org/licenses/by/4.0/). 